\title{
Evidence by Criminal Cases About Fraud with Using of Electronic Payment Facilities
}

\author{
Dmitry Tatianin ${ }^{1,}{ }^{*}$ Elena Tensina ${ }^{1}$ Larisa Tatianina ${ }^{1}$ \\ ${ }^{1}$ Udmurt State University, Izhevsk 426034, Russian Federation \\ "Corresponding author. Email: rok25-12@mail.ru
}

\begin{abstract}
In this article specific debatable questions about evidence by criminal cases about fraud which was made with using of electronic payment facilities are considered. Practically there are some questions of delimitation of criminal from civil matters and also determination of mechanisms of stealing with using of electronic payment facilities and uncovering people who have committed a crime. In order to ensure crime solution and investigation of such crimes we should define specifics of collecting evidences for this category of criminal cases, opportunities and limits of using specific knowledge. Result of research is definition of content of subject of evidence and establishment of its limits, verification of using particular means of evidence for specific type of stealing. In this work there was made a distinction between criminal and civil matters with using of electronic payment facilities, basic means of evidence which is used in such category of cases were generalized and obligatory participation of specialist during the carrying out of processual actions was validated.
\end{abstract} Keywords: Electronic payment facilities, evidence, subject of evidence, specialist, expert, expert's opinion.

\section{INTRODUCTION}

Development of technical progress led to constantly using of electronic payment facilities and this led to activization of different types of fraudsters who have started to create different ways of getting funds from bank accounts. If earlier crimes which were connected with frauds with using of electronic payment facilities were directed towards legal persons, afterwards citizens whose incompetence and trustingness led to the opportunity of committing different frauds became victims of such crimes. Fraudsters during stealing with using electronic payment facilities use methods of social engineering in relation to citizens [1, 38 p.]. Involvement high technologies and different electronic facilities into activity of criminal world caused necessity of law enforcement and judicial organs to use information technologies in their activities.

Problems of proceedings for criminal cases which were connected with using information technologies including electronic payment facilities were considered by many Russian scientists [1-9]. Problems of using information technologies in criminal procedure are actual not in Russia but also in other countries what follows from published works of such foreign authors as Goodman [10], Nissan [11], Smith et al. [12].

Growth of crimes connected with using of electronic payment facilities caused introduction in CC RF art. 159.3 "Fraud with using of payment cards" [13], which was edited by Federal Law from 23.04.2018 year № 111- FL and got the name "Fraud with using electronic payment facilities" [14]. Fact of acceptance such norm has not ensured protection from committing such crimes. Stealing of funds from bank account with using of electronic payment facilities does not have many difficulties [3,10 p.]. Electronic payment facilities are used not only during stealing in the form of fraud but also during money laundering [7, pp. 21-26].

Specific of committing fraud with using electronic payment facilities does not suppose direct contact fraudster with his victim and it makes process of evidence for criminal cases in this category more difficult. Because of this fact practically there are some difficulties during the definition of way of fraud with using of electronic payment facilities, its subject and others essential elements of offence. The most problematic in evidence is way of making a stealing (fraudulent conduct) and instrument of its making which is electronic payment facility. Increasing of amount of stealing connected with using electronic payment facilities determines necessity of creating methodology which guarantees qualitative investigation of such crimes and this determines newness of theme of the research.

\section{METHODS AND RESULTS}

In this work there were used such methods as observation, deduction, induction, using laws of formal logic, comparative analysis and technical method. The results can be briefly outlined as follows:

1. Circumstances which needed for evidence of fraud with using electronic payment facilities were established 
2. Stable tendency of changes in theory, law and practice connected with using of information technologies was set up

3. Basic perspective problems connected with using electronic payment facilities during fraud which needed further research were determined

\section{DISCUSSION}

Nowadays criminal law quite precisely regulates term of fraud connected with using electronic payment facilities. We should point out that legislator has precisely determined that we can relate to electronic payment facilities such means as payment card, electronic money and cash register equipment [8, pp. 66-68].

Simultaneously there are some questions connected with evidence of commitment fact of such crime. The most difficult in evidence is fraud with using payment cards, electronic money and money transfers. Practically and scientifically one of the most problematic questions is about means of stealing with using electronic payment facilities.

There are two approaches for solution this question. According to the first approach, fraudulent conduct is not in the fact of using electronic payment facilities but in situation when person makes other actions intended to deceive specific scope of persons [4, pp. 51-52]. The second approach means that acknowledgement of existence of fraudulent conduct must have place in case when guilty person uses electronic payment facilities for the purpose of stealing $[9,10 \mathrm{p}$.]. We suppose that the second approach is correct and person deliberately use electronic payment facilities for stealing.

Debatable question is about evidence of subjective side of fraud with using electronic payment facilities. Certainly, that such crimes can be made only with direct intention but using electronic facilities allows to speak about mistake which was caused through the fault of victim in connection with incorrect indication of pincode, recipient address and so on. In connection with it we should establish reason and mechanism of money transfer using electronic payment facilities. In case if money transfer is caused by recipient interacted to the owner of money through his delusion through giving incorrect information such situation will say about direct intention of guilty person for using electronic payment facilities. Offer to transfer money with providing address for transfer to individual cannot have undeliberate and accidental nature. We should consider existent of direct intention in the activities of people who deceive owners of electronic payment facilities presented themselves as bank officials and offered to maintain an operation for deposition in order to ensure their security. In this case nature of activities of these people can say about making actions with deceptive purposes and direct intention.

Peculiarity of fraud with using electronic payment facilities is absence of material objects as subject of stealing. Denying fact of absence about material evidences and injuries for such category of criminal cases is unacceptably because according to p.13.1 art.5 CPC of the RF which was introduced by Federal Law № $190-F L$ from $29^{\text {th }}$ July 2015 "estate is anything including cash-based transfers and certificate securities, noncash money on the accounts and deposits in banks or other credit companies, uncertificated securities rights on which are regarded in register of owners of uncertificated securities or depositories, rights to possession including legal claim and exclusive rights" [15].

Grigoriev points out that "uncertificated securities are liable to acknowledgement as material evidence for two features: as subjects to which criminal actions were directed and as other estate gotten because of crime if the fact of stealing of shares has been confirmed" [5, 206 p.]. We suppose that we should make an analogy between uncertificated securities and non-cash money existed on the accounts and deposits in banks or other credit companies. During fraud with using electronic payment facilities on the one hand criminal actions are directed to money which are in the bank deposits and in the deposits, on the other hand parties during the fact of stealing can be as estate gotten because of criminal action. As a result, non-cash money existed on the accounts and deposits in banks or other credit companies must be considered as material evidence in criminal cases.

One of debatable question is about keeping of funds gotten because of fraud with using electronic payment facilities. Whereas these funds arrive as non-cash transfers, we suppose that special keeping condition of material evidence must spread to them. This condition was established by st.3.1 p.2 art.82 CPC of the RF which said that money, valuables and other estate gotten because of crime and revenues from this estate which were found during investigative activities are subject to arrest in procedure which was established by the article $115 \mathrm{CPC}$ of the RF.

As a result, money gotten with using electronic payment cards and through money transfers must be acknowledged material evidence and it should be arrested by the act of court in procedure by the article 165 CPC of the RF. Detection and arrestment to electronic money which does not need tax recording is more problematic and this makes its revelation more difficult.

There are questions about determination of jurisdiction during the investigation of crimes in informational space and some authors have pointed out to this fact [2, pp. 24-31], [6, pp. 54-58]. Suggestion about making a 
payment can come from the territory of one state and then person will make transfer while he is at the territory of the other state and there is question about investigation site of the crime. Modern technologies afford to establish place where information has been come to the owner of plastic card or electronic money in most cases but this will depend on different factors including access time of declaration. If we take into account that such crimes are committed with getting money which are situated on accounts in credit organizations of specific state so crime should be investigated in the state where client had money. Such situation is connected with protection of bank secrecy because making intelligence gathering and investigative actions for such categories of criminal cases are linked with its restriction and it does not suppose an opportunity to access law enforcement officials for such activity.

\section{SUMMARY}

Overall, we suppose that proceeding for the criminal cases about fraud with using electronic payment facilities must be done in the state where client has had money independently from in what state the payment operation was done

Subjects of crime for such category of cases are electronic payment facilities such as: payment card, electronic money, money transfer and cash register equipment. However, subject of crime for this category of cases has changeable nature because development of high technologies and opportunity of their using in credit and financial sphere affords us to make a conclusion about creating new electronic payment facilities. Considering this situation, we should determine term of electronic payment facilities relating to structure of fraud with its using in such way in order to appearance of new electronic payment facility can be considered as subject of crime in the investigating crime at once.

In addition, the position about necessity of considering non-cash money on bank accounts and in deposits as material evidence for criminal cases was proven.

During the determination of subjective side of fraud with using electronic payment facilities we should take into account activity of particular person about influencing to supposed victim in order to persuade him to make specific payment operation.

\section{CONCLUSIONS}

As a result, peculiarities of evidence of fraud connected with using electronic payment facilities caused by making non-cash operations in relation to money which exists on the client's bank account and it affords to make these operations remotely from lending financial institution through the Internet, automatic tellers and so on. We should consider non-cash money as material evidence which was as subject of criminal offence and was seized from the account of particular client and so he had property damage by these actions.

Considering development of high technologies, we should define the term of electronic payment in such a way that if new electronic facility appears it will fall under existent term and we will not have any questions practically about definition of the nature of actions and consequences connected with its using for purposes of getting money illegally.

\section{REFERENCES}

[1] B.E. Shavaleev, Peculiarities of fraud with using electronic payment facilities in the structure of modern Russian criminality, Scientific notes of Kazan Law institute MIA of Russia 5(9) (2020) 36-38.

[2] E.L. Anselmno, Cyberspace in international law: does internet development contradict with territorial principle in international law? Economic strategies 2 (2006) 24-31.

[3] A.Yu. Buravtseva, Stealing with using electronic payment facilities from bank account as well in relation to electronic funds, Juridical fact 47 (2019) 10-12.

[4] S.A. Vorozhtsov, About legal practice about fraud, impropriation or misapplication, Law 11 (2008) 51-53.

[5] V.N. Grigoriev, Uncertificated securities as material evidence: holding procedures, in: Materials of XIII International scientific and practical conference on Actual problem of law in Russia and CIS, Poligraf master, Chelyabinsk, 2016, pp. 204-212.

[6] I.S. Iskevich, M.N. Kochetkova, A.M. Popov, Actual problems of definition of jurisdiction during investigation criminals in informational space: international and legal aspect, Problems of law enforcement activities 2 (2016) 54-58.

[7] M.I. Kaznova, A.E. Ovchinnikova, Using electronic payment facilities to money laundering and sponsorship of terrorism, Challenges and opportunities of financial security of stable economic growth, in: Materials of all-Russian scientific and practical conference, SSU, Sevastopol, 2017, pp. 21-26.

[8] E.I. Kolesnikova, Electronic payment facilities, Tax policy and practice 2(182) (2018) 66-70.

[9] Yu.Yu. Malysheva, Problems of classification of fraudulent action as way of making fraud with using electronic payment facilities, Monitoring of enforcement 4(29) (2018) 31-33. 
[10] M. Goodman, International Dimensions of Cybercrime, in: S. Ghosh, E. Turrini (Eds.), Cybercrimes: A Multidisciplinary Analysis, Heidelberg, 2010, 361 p.

[11] E. Nissan, Legal Evidence, Police Intelligence, Crime Analysis or Detection, Forensic Testing, and Argumentation: An Overview of Computer Tools or Techniques, International Journal of Law and Information Technology 17(1) (2009) 1-82. DOI: https://doi.org/10.1093/ijlit/ean009

[12] R.G. Smith, P. Grabosky, G. Urbas, Cyber Criminals on Trial, International Journal of Law and Information Technology 58(1) (2004) 22-23. DOI: https://doi.org/10.1080/09627250408553240

[13] About making changes into Criminal Code of the Russian Federation and specific legislative acts of the Russian Federation: Federal Law of the Russian Federation № 207-FL from $29^{\text {th }}$ November 2012// Official gazette- 2012 - № 49 - Art. 6752.

[14] About making changes into Criminal Code of the Russian Federation and specific legislative acts of the Russian Federation: Federal Law of the Russian Federation № 111-FL from $23^{\text {rd }}$ April 2018// Official gazette2018 - № 18 - Art.2581.

[15] About making changes into Criminal Code of the Russian Federation and specific legislative acts of the Russian Federation: Federal Law of the Russian Federation № 190-FL from $29^{\text {th }}$ July 2015// Official gazette2015 - № 27 - Art.3981. 